\title{
Sürdürülebilir Eko-Turizm Destinasyonları Olarak Sulak Alanlar: Uluabat Gölü
}

\author{
Aysun Çelik Çanga ${ }^{*}$ iD Tülay Polat Üzümcï ${ }^{2}$ \\ ${ }^{1}$ Bursa Uludağ Üniversitesi, Ziraat Fakültesi, Peyzaj Mimarlığı Bölümü, Nilüfer-Bursa \\ ${ }^{2}$ Kocaeli üniversitesi, Kartepe Turizm MYO, Kartepe/Kocaeli \\ *Sorumlu yazar: aysncelik@uludag.edu.tr
}

Geliş Tarihi: 12.05.2020

Kabul Tarihi: 04.12.2020

\section{Öz}

Sürdürülebilir turizm; çevresel kaynakları en uygun şekilde kullanmayı, temel ekolojik süreçleri sürdürmeyi, doğal mirası ve biyolojik çeşitliliği korumayı hedefleyen turizmdir. Sulak alanlar doğal ve kültürel peyzaj çekicilikleriyle turist çekme potansiyeli yüksek olan alanlar olup, aynı zamanda dünyanın en kırılgan ekosistemlerinden birisidir. İyi planlanmamış ve iyi yönetilmeyen rekreasyon ve turizm faaliyetleri sulak alanların bozulmasında itici güç olabilmekte ve bu alanların ekosistem hizmetlerinin sürekliliğini tehlikeye atabilmektedir. Sürdürülebilir turizm destinasyonları olarak sulak alanların değerlendirilmesi ve alana özgü turizm türlerinin belirlenmesi; alana özgü kaynak değerlerinin, ekolojik süreçlerin, biyolojik çeşitliliğin, yerel kültürel özelliklerin değerini anlayarak korumayı ve devamlılığını sağlar nitelikte yönetmeyi gerektirmektedir. Bu çalışmada; Uluabat Gölü doğal ve kültürel çevre özelliklerinin turizm ile ilişkisi kurularak, turizm faaliyetleri için kriterlerin ve koruma kültürünün benimsendiği turizm türlerini belirlemek amaçlanmıştır. Araştırmanın veri toplama aracı; arazi surveyi ve literatür araştırmalarıdır. Uluabat Gölü doğal ve kültürel çevre özelliklerinin turizm ile ilişkisinin kurulabilmesi için gerekli olan verileri arazi çalışmaları yanı sıra literatür araştırması ile tamamlanmıştır. Bu araştırmada, ulaşılan her türlü materyalin içeriği sistematik ve detaylı bir şekilde incelenmiş, çıkarımlar yapılmıştır. Elde edilen bütün verilerin analizi sonucu ulaşılan bilgiler amaç doğrultusunda ve uzman bakış açısı ile yorumlanmıştır. Araştırmanın sonucunda; turizm amaçlı sulak alan kullanımı ve koruma kültürünün birbirinden karşılıklı olarak yararlandıkları turizm türleri belirlenmiş, uygulanabilir öneriler geliştirilmiştir.

Anahtar Kelimeler: Sürdürülebilir turizm, eko turizm, turizm destinasyonu, sulak alan, Uluabat Gölü

\section{Wetlands as Sustainable Eco-Tourism Destinations: Lake Uluabat}

\section{Abstract}

Sustainable tourism; tourism, which aims to use environmental resources in the most appropriate way, to maintain basic ecological processes, and to protect natural heritage and biodiversity. Wetlands are areas that have high potential to attract tourists with their natural and cultural landscape values, and are also one of the most fragile ecosystems in the world. Poorly planned and poorly managed recreation and tourism activities can be the driving force in degradation of wetlands and endanger the continuity of ecosystem services of these areas. Evaluation of wetlands as sustainable tourism destinations and determination of specific tourism types; Understanding the value of the area-specific resource values, ecological processes, biodiversity, and local cultural characteristics requires the management to provide protection and continuity. In this study; By establishing the relationship between the natural and cultural environment features of Uluabat Lake with tourism, it is aimed to determine the types of tourism where the criteria and protection culture are adopted for tourism activities. The data collection tool of the research; field survival and literature research. The necessary data for the relationship between the natural and cultural environment features of Uluabat Lake and tourism has been completed by field research as well as literature research. In this research, the content of any material reached was examined systematically and in detail, and inferences were made. The information obtained as a result of the analysis of all the obtained data was interpreted in line with the purpose and with an expert perspective. As a result of the research; Tourism types, in which the use of wetlands for tourism and conservation culture are mutually benefited from, have been determined and feasible suggestions have been developed.

Keywords: Sustainable tourism, ecotourism, tourism destination, wetland area, Uluabat Lake 


\section{Giriş}

Sürdürülebilir turizm; ziyaretçiler, çevre, turizm sektörü ve yerel halkın bugünkü ve gelecekteki turistik ihtiyaç ve beklentilerinin karşılanmasını öngören bir yaklaşımdır (Ödemiş ve Çalık, 2019). Sürdürülebilir turizm, turizmin kullandığı kaynakların kontrol altına alınarak doğal çevreye verebileceği zararları en aza indiren ve aynı zamanda da turizmin olumlu sosyal, kültürel ve ekonomik etkilerini en üst seviyeye çıarmayı hedefleyen turizm türlerini kapsamaktadır. Bunlar da çoğunlukla eko turizm türlerini kapsamaktadır.

Günümüz insanları psikolojik ve fiziksel sağlıkları için doğal çevre ile iç içe olabilecekleri alanlarda turistik faaliyetlerde bulunmayı tercih etmektedirler. Çünkü doğal alanlar; iklim özellikleri, yaban hayatı, bitki örtüsü, su kaynakları, kırsal yaşam tarzı, manzara güzelliği gibi doğal ve kültürel peyzaj bileşenleri ile turistik çekiciliğe sahip alanlardır. Pasif bir etkinlikle bile olsa doğal alanlarda bulunmak, insanların yaşadıkları çevreyi sevmelerine, mutlu, huzurlu olmalarına ve doğayı tanımalarına katkı sağlamaktadır. Doğal alanlardaki çeşitli aktif etkinlikler ise insanlara yeni yetenekler kazandırmaktadır. Doğal çevre koşullarında gerçekleşen ve doğal alanlara, yerel kültürel özelliklere, geleneksel özgünlüğü korumaya duyarlı olan bu turizm türü Eko-Turizmdir. Burada ziyaretçilerin doğal ve kültürel peyzaj değerleri üzerindeki olumsuz etkileri en alt düzeydedir. Ekoturizm, doğal kaynakların sürdürülebilirliğini güvence altına alarak, yerel halkın hem ekonomik olarak kalkınmasını sağlamakta, sosyal ve kültürel bütünlüklerini de korumaktadır (Koçan, 2011). Ekolojik, sosyal ve kültürel bütünlük ile sorumluluk ve sürdürülebilirlik ekoturizmin kalitesini belirlemektedir (Khabbazi ve Yazgan, 2012). Eko-turizm, alternatif turizm türlerinin, doğal ve kültürel değerlere saygılı ve bilinçli tüketicilerin sayısının artmasına paralel hızla gelişmektedir (Gülbahar, 2009).

Sulak alanlar biyolojik çeşitlilikleri nedeniyle dünyanın doğal zenginlik müzeleri olarak kabul edilmektedir. Sulak alanlar; suların toplanması, sulama ve atıksu yönetimi, taşkın koruma için suyun bulunabilirliği, biyo-çeşitlilik dönüşümü, balık stokları, güvenli içme suyu temini ve su kalitesini iyileştirme vb. konularda yaşamsal öneme sahiptir (Tockner ve ark., 2010; Ostrovskaya ve ark., 2012). İlaveten sulak alanlar karasal hayvanlar ve kuşların besin sağlamak için kullanması sebebiyle, çok sayıda kuş çeşidini barındırmaktadır (Zaimoğlu ve Bozkurt, 2010). Bunların yanında sulak alanların, insan refahı, yaban hayatı ve çevresel kalitenin sürdürülebilmesi için de önemli yararları bulunmaktadır (Güney, 2014). Dünyanın en önemli doğal alanlarından olan sulak alanlar; ekolojik önemlerinin yanı sıra içme, kullanma, sulama ve farklı endüstri kollarının sularını karşılama, saz kesimi, balıkçılık, hayvancılık, ulaşım, eğitim-araştırma, turizm ve rekreasyonel faaliyetlere sağladığı olanaklar ile ekonomik değere sahip alanlardır.

Türkiye 13 Kasım 1994'de Ramsar Sulak Alanlar Sözleşmesi'ne taraf olduğundan ülkemizde sulak alanların sınıflandırılması bu sözleşmeye göre yapılmaktadır. $\mathrm{Bu}$ sözleşme kriterlerine göre Türkiye'de 1327 sulak alandan 135 adedi Uluslararası Öneme Sahip Sulak Alan olarak belirlenmiştir. Ayrıca 76 alandan 56'sı su kuş, 4'ü balık, 16' sı ise hem su kuşları hem de balık kriterleri bakımından uluslararası öneme sahiptir (WWF, 2008). Bu uluslararası öneme sahip 135 sulak alandan 13 tanesi Ramsar Sözleşmesi doğrultusunda koruma altına alınıp Ramsar Alanı olarak belirlenmiştir. Bu alanlar Çizelge 1'de verilmiştir.

Çizelge 1. Türkiye'nin Ramsar Alanları (Anonim, 2019)

\begin{tabular}{llll}
\hline Ramsar Alanları- Bulunduğu İl & Ramsar Tarihi & Ramsar Alanları- Bulunduğu İl & Ramsar Tarihi \\
\hline Kuş (Manyas) Gölü- BALIKESİR & 13 Temmuz 1994 & Akyatan Lagünü- ADANA & 15 Nisan 1998 \\
Burdur Gölü- BURDUR & 13 Temmuz 1994 & Gediz Deltas1- İMİR & 15 Nisan 1998 \\
Sultansazlı̆̆1- KAYSERİ & 13 Temmuz 1994 & Yumurtalık Lagünü- ADANA & 21 Haziran 2005 \\
Seyfe Gölü- KIRŞEHİR & 13 Temmuz 1994 & Meke Gölü- KONYA & 21 Haziran 2005 \\
Göksu Deltas1- MERSİN & 13 Temmuz 1994 & Kizören Obruğu- KONYA & 2 May1s 2006 \\
Kizılırmak Deltas1- SAMSUN & 15 Nisan 1998 & Kuyucuk Gölü- KARS & 2 Nisan 2009 \\
\hline Uluabat Gölü- BURSA & 15 Nisan 1998 & & \\
\hline
\end{tabular}

Türkiye'de yerli ve yabancı turistleri kendine çeken sulak alanlardan birisi de, bu çalışmanın konusu olan Uluabat Gölü'dür. Uluabat Gölü, Bursa, Kütahya, Balıkesir ve Bilecik il sınırları içerisinde yer almaktadır (Şekil 1). 


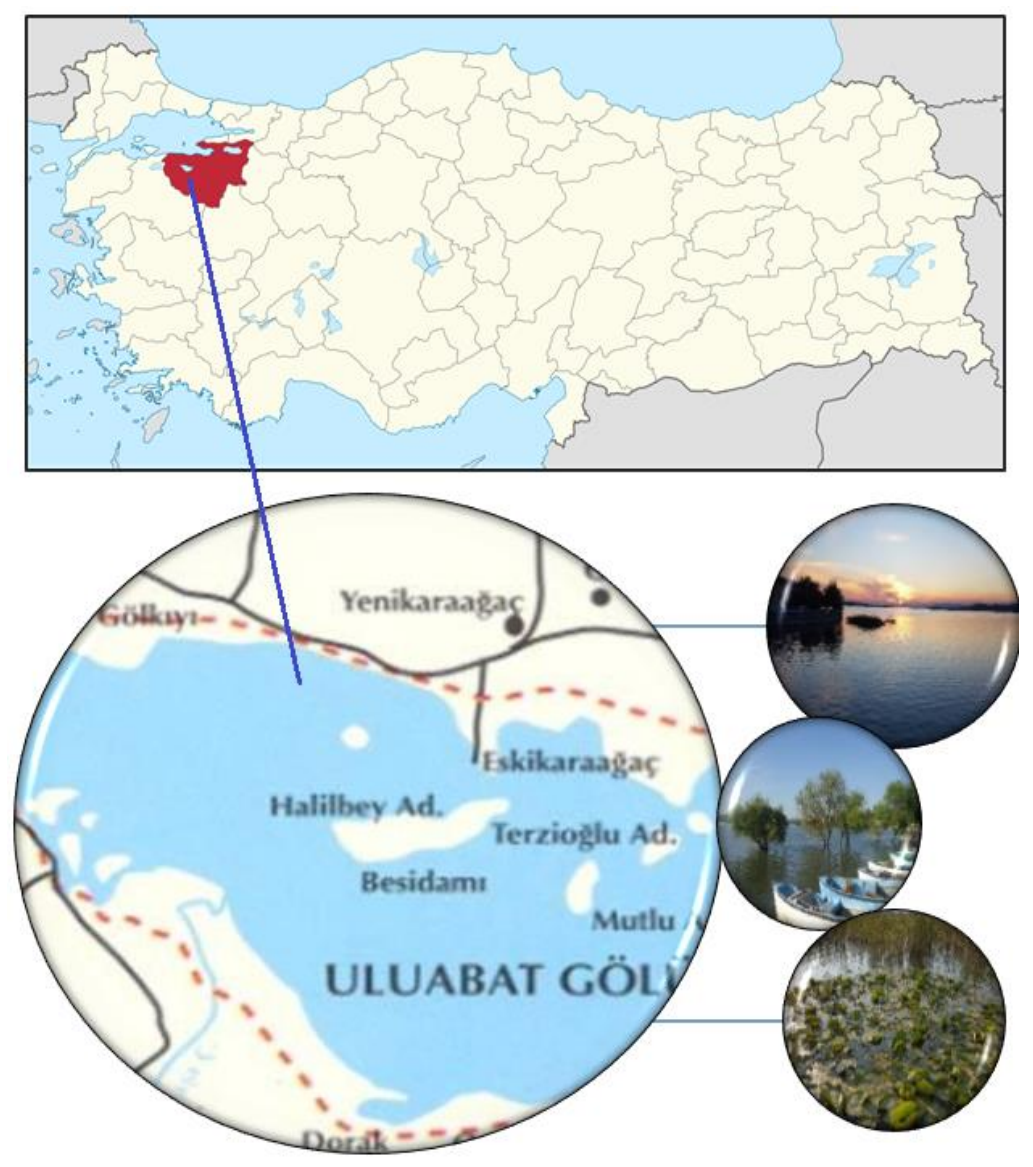

Şekil 1. Uluabat Gölü

Uluabat gölü büyüklük bakımından Türkiye'deki 9.büyük göl olup (Anonim, 2016), gölün alanı 19900 ha, deniz seviyesinden yüksekliği 8 metre, doğu-batı yönünde uzunluğu $23-24 \mathrm{~km}$. genişliği ise $12 \mathrm{~km}$ kadardır. Gölün derinliği bir çok yerde 2- 2,5 m civarında olup bu derinlik yaz aylarında 1,5 metreye kadar gerilerken (Dalkıran ve ark., 2006), göl içerisinde 7 adet ada bulunmaktadır. Gölü besleyen en önemli su kaynağı Mustafakemalpaşa Çayı olup, gölün fazla suları gölün batısındaki Uluabat Deresiyle Susurluk Çayı'na ve bu çay vasıtasıyla da Marmara Denizi'ne boşalmaktadır. Göl çevresinde ve göle sınırı olan 17 yerleşim birimi bulunmaktadır (Anonim, 2020a). Göl Ramsar Statüsü ve Yaşayan Göller A ğı'na dahil edilmiş, korunan bir alandır. Uluabat Gölü tipik bir sığ göl olup, bazı küresel ölçekte nesli tehlike altında türler barındırmakta ve sucul bitkiler yönünden Türkiye'nin en zengin sulak alanlarındandır. Göl ve çevresinde, plansız yapılan turizm kaynaklı olumsuzluklardan biyoçeşitliğin korumasına yönelik düzenlemeler çok yetersizdir. Bu nedenle bu çalışmanın konusu olarak seçilmiştir. Bu çalışmada; Uluabat Gölü doğal ve kültürel çevre özelliklerinin turizm ile ilişkisi kurularak, turizm faaliyetleri için kriterler ve koruma kültürünün benimsendiği turizm çeşitlerini belirlemek amaçlanmıştır.

\section{Materyal ve Yöntem}

Çalışmanın ana materyalini Uluabat Gölü ile ilgili yazılı kaynaklar, kitap, makale, rapor, belge, tezler, alanda yapılan gözlemlerle edinilen izlenimler ve bu esnada çekilen fotoğraflar oluşturmaktadır. Araştırma yöntemi Şekil 2' de görüldüğü gibi 5 aşamadan oluşmaktadır. Konu, amaç ve kapsamın belirlenmesinden sonraki aşama veri toplama sürecidir. Uluabat Gölü doğal ve kültürel çevre özelliklerinin turizm ile ilişkisinin kurulabilmesi için gerekli olan veriler arazi çalışmaları yanı sıra literatür araştırması ile elde edilmiştir. Bu araştırmada, ulaşılan her türlü materyalin içeriği sistematik ve detaylı bir şekilde incelenmiş, çıkarımlar yapılmıştır. Elde edilen bütün verilerin analizi sonucu ulaşılan bilgiler amaç doğrultusunda ve uzman bakış açısı ile yorumlanarak Uluabat Gölü’nün doğal ve kültürel peyzaj değerlerinin varlığını sürdürmesini sağlayan eko turizm türleri belirlenmiş, 
koruma kültürü ile turizm faaliyetleri arasında simbiyotik ilişkiyi kurmaya yönelik öneriler getirilmiş ve sonuçlara ulaşılmıştır.

\section{ASAMA: Konunun Belirlenmesi ( Burada konu bir sorundur)}

- Uluabat Gölü 1. derece doğal sit statüsünde korunan bir alan olmasına rağmen, bu alanda plansız yapılan rekreasyonel ve turistik faaliyetler doğal yapıya geriye dönülmez bir şekilde zarar vermektedir. Koruma kültürüne dayalı bir kullanım söz konusu değildir.

\section{AȘAMA: Amaç ve Kapsamın Belirlenmesi}

•Amaç : Uluabat Gölü doğal ve kültürel çevre özellikleri ile turizm ilişkisini kurarak her ikisinin de varlığını sürekli kılacak olan turizm türlerini belirlemektir.

-Kapsam: Fiziki kapsam; Uluabat Gölü, göl içindeki 7 ada ve yakın çevresindeki köylerdir. Çalışma içeriği ; Turizm türlerini belirlemek, blirlenen turizm türlerine yönelik planlama ve tasarım kriterleri oluşturmaktır.

\section{AȘAMA:Verilerin Toplanması}

-Arazi çalıșmasına dayalı veri toplama (Çalışma alanında inceleme ve gözlemlerde bulunularak edinilen izlenimlerle oluşturulan veriler, fotoğrafların çekilmesi)

- Literatür araştırmasına dayalı veri toplama ( Ekoturizm, sürdürülebilir turizm, Uluabat Gölü ve çevresinin doğal ve kültürel peyzaj özellikleri konularında literatür verilerinin oluş̧urulmasi)

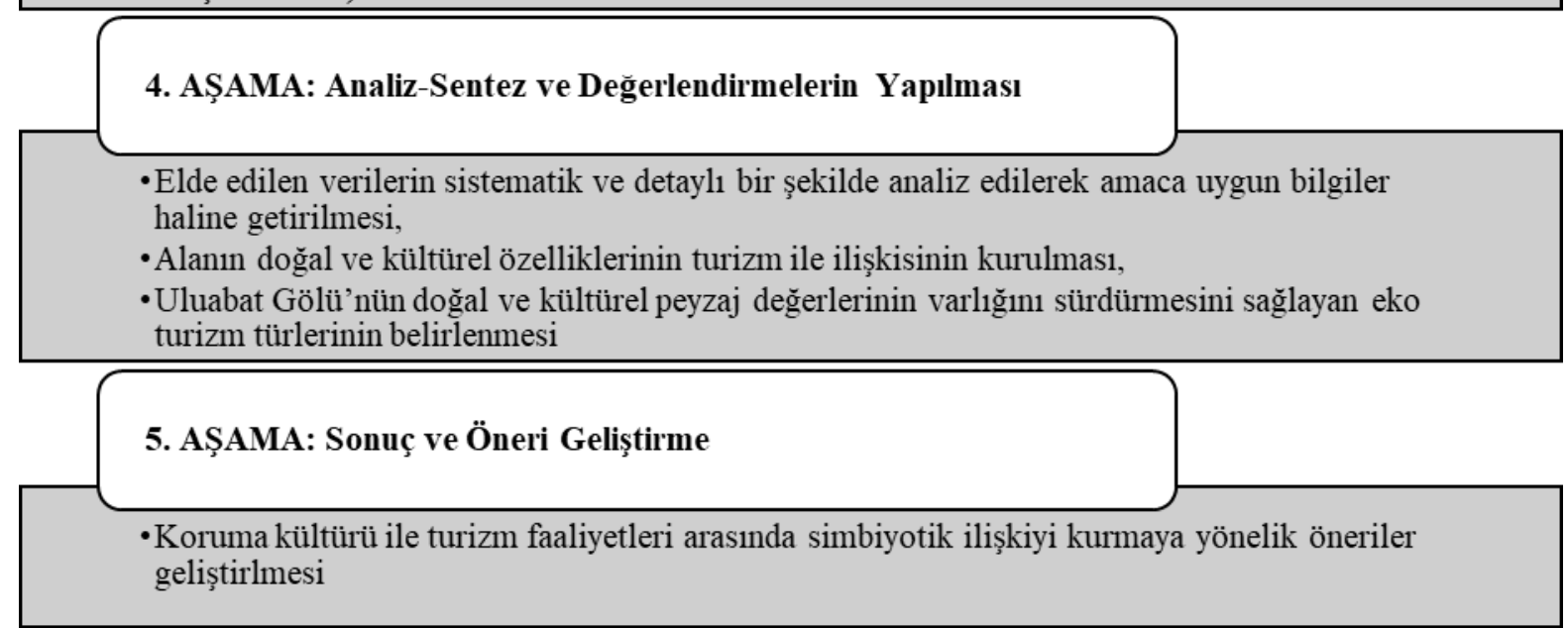

Şekil 2. Yöntem akış1

\section{Bulgular ve Tartışma}

Sürdürülebilir turizm destinasyonu olarak sulak alanların kullanımı, rekeasyonel ve turistik faaliyetlerin sulak alan peyzajı ve yaban yaşamı üzerindeki etkilerini en aza indirgemekle ilgili olup, sulak alanların sürekliliğini sağlamaya odaklı olmalıdır. Bunun için de; sulak alanın çevresini ve kırılgan habitatlarını korumak, taşıma kapasitelerini dikkate almak gerekmektedir. Bu kapsamda Uluabat gölünün bir sürdürülebilir turizm destinasyonu olarak; faunas1, florası, manzara kalitesi, ek diğer özellikleri ve bu doğrultuda geliştirilebilecek turizm türleri aşağıda belirtilmektedir.

Uluabat Gölü sucul bitkiler yönünden Türkiye'nin en zengin sulak alanlardan birisi olup, hemen hemen tüm kıyıları geniş sazlıklarla, sığ kesimleri ise su içi bitkilerle kaplıdır. Çevresi sazlık olan gölün doğu kıyısı dışındaki kıyıları nilüferlerle kaplıdır. Bu yönü ile Türkiye'nin en büyük nilüfer yataklarına sahip olup, fazla olan bitki grubu kamış ve sazdır. Uluabat Gölü yaygın bitkileri Çizelge 2' de verilmiştir. 
Çizelge 2. Uluabat Gölü Bitkileri (Seçmen ve Leblebici, 1997; Ertem ve Akkaya, 1997; Welch ve Welch, 1998).

\begin{tabular}{|c|c|}
\hline Genus & Genus \\
\hline Agrostis stol-onifera (Stolonlu Tavusotu) & Paspalum paspolodes (Su Ayrığı) \\
\hline Alopecurus myosuroides (Tilki Kuyruğu) & Phragmites austrialis (Cav.) Tria. Ex. Steud (Kamıs) \\
\hline Artemisia santaricum (Yavşan) & Polygonum amphibium L. (Su Çoban Değneği) \\
\hline Azolla (Kırmızı Eğrelti) & Polygonum lapathifolium L. (Boğumlu Çoban Değneği) \\
\hline Bolboschoenus maritimus Palla var. maritimus (Deniz Sandalye Sazı) & Potomogeton panormitanus Biv. (Küçük Su Sümbülü) \\
\hline Bromus hordeaceus (Başakotu) & Potamogeton crispus L.(Kıvırcık Su Sümbülü) \\
\hline Butomus umbellatus L. (Çiçekli Hasırsazı) & Potamogeton perfoliatus L. (Sapsız Yapraklı Su Sümbülü) \\
\hline Ceratophyllum demersum L. (Tilkikuyruğu) & Salicornia (Börülce) \\
\hline Chara spp (Su Avizeleri) & Salix(Söğ̈̈t) \\
\hline Cortaderia (Bataklık Sandalye Sazı) & Sagittaria sagittifolia $L . \quad(\mathrm{Su} \mathrm{Oku})$ \\
\hline Cyperus longus L. (Kırkboğum) & Scirpoides holoschoenus (L.) Sojak (Top Sandalye Sazı) \\
\hline Eichhornia crassipes (Su Sümbülü) & Scirpus (Deniz Sandalye Sazı ) \\
\hline Eleocharis palustris $L$. Br. (Bataklık Sandalye Sazı) & Scirpus maritimus (Su Sandalye Sazı) \\
\hline Herniaria (Mızraklı Kaşık Otu) & Schoenoplectus lacustris L. ssp. lacustris (Su Sandalye Sazı) \\
\hline Hordeum marinum (Yabani Arpa) & Schoenoplectus littoralis (Schrader) Palla (Kıy1 Sandalye Sazı) \\
\hline Lemna minor L. $\quad$ (Küçük Su Mercimeği) & Sparganium erectum L. Ssp. Erectum (Dik Sığır Sazı) \\
\hline Lemna trisulca $\mathrm{L}$. (Zincirsi Su Mercimeği) & Stachys palustris(Adaçayi) \\
\hline Myriophyllum spicatum L. (Başaklı Su Civan Perçemi) & Tamarix (Ilgın) \\
\hline Najas marina L. (Dikenli Superisi) & Typha (Hasır Otu) \\
\hline Najas minor All. (Küçük Superisi) & Typha domingensis Pers.(Dar Yapraklı Saz) \\
\hline Nymphaea alba (Beyaz Nilüfer) & Utricularia austrialis (Ufak Su Miğferi) \\
\hline Potamogeton lucens L. (Parlak Su Sümbülü) & Vallisneria spiralis $L$. (Yılanbalı̆̆ı Otu) \\
\hline Potamogeton nodosus Poir. (Boğumlu Su Sümbülü) & Verbascum (Dik Sığır Sazı) \\
\hline
\end{tabular}

Göl, Anadolu'ya kuzeybatıdan giren kuş göç yolu üzerinde olması, önemli kuş alanlarından Kuş Gölü'ne çok yakın mesafede $(35 \mathrm{~km})$ bulunması, besin maddeleri bakımından zengin olması ve uygun iklim koşullarının varlı̆̆ farklı türden ve kalabalık kuş gruplarının göl ve çeversinde beslenmesine, kışlamasına ve üremesine olanak sağlamaktadır. Bu alan küresel boyutta nesli tehlike altında olan Phalacrocorax pygmeus, Aythya nyroca, Pelecanus crispus, Chlidonias hybridus türlerine de ev sahipliği yapmaktadır (Çizelge 3). Uluabat Gölü balık taksonları Çizelge 4'de verilmiştir.

Çizelge 3. Uluabat Gölü Önemli Kuş Türleri(Dalkıran, 2015)

\begin{tabular}{ll}
\hline Genus & Genus \\
\hline Ardea purpurea (Ergüvani Balıç̧ı) & Ixobrybcus minutus (Küçük Balaban) \\
Ardeola ralloides (Alaca Balıçıl) & Microcarbo pygmeus (Küçük Karabatak) \\
Aythya ferina (Elmabaş Patka) & Nycticorax Nycticorax (Gece Balıkçılı) \\
Aythya nyroca (Pasbas Patka) & Pelecanus crispus (Tepeli Pelikan) \\
Aythya fuligula (Tepeli Patka) & Pelecanus onocrotalus (Ak Pelikan) \\
Chlidonias niger (Kara Sumru) & Phalacrocorax pygmeus (Küçük Karabatak) \\
Chlidonias hybridus (Bıyıklı Sumru) & Plegadis falcinellus (Çeltikçi) \\
Circus aeruginosus (Saz Delicesi) & Platalea leucoradia (Kaşıçı) \\
Egretta garzetta (Küçük Ak Balıçıl) & Podiceps cristatus (Bahri) \\
Fulica atra (Sakarmeke) & Vanellus spinosus (Mahmuzlu Kıkkuşu) \\
Glareola pratincola (Bataklık Kırlangıcı) & \\
\hline
\end{tabular}

Çizelge 4. Uluabat Gölü Balık Türleri (Çubuk, 2000; Çınar ve ark., 2013; Dalkıran, 2015)

\begin{tabular}{ll}
\hline Genus & Genus \\
\hline Alburnus alburnus L. (İnci Balığı) & Leuciscus cephalus L. (Ak Balık) \\
Alosa maeotica (Ringa Balığı) & Mugil cephalus L.(Has Kefal) \\
Anguilla anguilla L. (Yılan Balığı) & Nemachilus angorae (Çöpçü Balığı) \\
Barbus plebejus (Bıyıklı Balık) & Proterorhinus marmoratus Phallas (Japon Sazanı) \\
Blicca björkna L. (Tahta Balığı) & Pseudorasbora parva (Çakıl Balığı) \\
Carassius gibelio Bloch (Gümişi Havuz Balığı) & Rhodeus sericeus Bloch.(Acı Balık) \\
Chalcalburnus chacloides (Tatlısu Kolyozu Balığı) & Rutilus rutilus L. (Kızılgöz Balığı) \\
Clupeonella abrau muhlisi (Tatlısu Sardalyası) & Scardinius erythrophthalmus L. (Kızılkanat Balığı) \\
Cobitis taenia L. (Taş Yiyen Balı̆̆ı) & Silurus glanis L.(Yayın Balığı) \\
Cyprinus carpio L.(Sazan Balığı) & Sygnathus acus (Deniziğnesi Balığı) \\
Esox lucius L.(Turna Balığı) & Syngnathus nigrolineatus Eichwald \\
Gobius fluviatilis Pallas (Tatlısu Kaya Balı̆̆ı) & Tinca tinca L.(Kadife Balığı) \\
Knipowitschia caucasica Kawrajsky (Kaya Balığı) & Vimba vimba L. (Eğrez Balığı) \\
\hline
\end{tabular}

Göldeki en önemli su ürünlerinden birisi de Astacus leptodactylus (kerevit) 'tur. Balık ve kerevit yanı sıra gölde yaşayan diğer canlılar da Rana ridibunda (Bataklık Kurbağası) ve Natrix natrix 
(Su Y1lanı) dir. Clupeonella abrau muhlisi (Tatlı Su Sardalyası) endemik ve küresel tehdit altındaki türlerdendir.

Göl çevresinde yaşayan memeli türlerden bazıları küresel ölçekte nesli tehlike altındadır(Çizelge 5).

Çizelge 5. Uluabat Gölü Çevresinde Küresel Ölçekte Nesli Tehlike Altında Olan Memeli Türler (Dalkıran, 2015)

\begin{tabular}{lll}
\hline Genus & Genus & Genus \\
\hline Lutra lutra (Su samuru) & Vulpes vulpes (Tilki) & Lepus europaeus (Tavşan) \\
Canis aureus (Çakal) & Meles meles (Porsuk) & \\
\hline
\end{tabular}

Uluabat Gölü 15.04.1998 yılında Ramsar alanı ilan edilmiş, 2001 yılında ise Yaşayan Göller Ağı'na dahil edilmiştir. Bugün Uluabat Gölü bu ağa dahil 55 gölün 24 ortak kuruluşundan bir tanesidir. Uluabat Gölü 1. derece doğal sit, Göl kıyısındaki Gölyazı Köyü de 1.derece arkeolojik sit statüsünde korunmaktadır. Bu alanı rekreasyon ve turizm faaliyetleri için çekici kılan değerler, aynı zamanda korunan alan olmasını da gerektiren değerlerdir (Çelik ve ark., 2016). Sulak alan ekosistemleri, yüksek ekolojik değerlere sahip olması nedeni ile taşıma kapasiteleri düşük olup sınırlı sayıda turist ağırlayabilen yerlerdir.

$\mathrm{Bu}$ alan, turistik faaliyette bulunan kişilerin doğa ile kopan bağını yeniden kuran, güçlendiren bir alandır. Su insan psikolojisinde çok güçlü etkilere sahiptir. İnsanları rahatlatır, rehabilite eder, sakinleştirir, huzur verir, dinlendirir, konsantrasyon artırır, fiziksel olarak gevşetir, stresten arındırır. $\mathrm{Bu}$ nedenle, rekreasyon ve turizm amacı ile en çok tercih edilen alanlardır. Uluabat Gölü de sakinliği, su bitkileri, balıkları, kıyıdaki sandalları, su içerisinde kalmış ağaçları ve üzerindeki çeşitli kuşları ile doğal estetiğe sahip manzara kalitesi yüksek bir peyzajdır. Ziyaretçilerin ruhunu dinlendiren ve kentlerin stresli ortamından kaçmak isteyen turistler için çekici bir alandır. Ayrıca, kentsel alanlardaki süs bitkileri ile donatılmış alanlardan farklı olarak sazlıkları, su bitkileri ve türbiyerleri ile estetik açıdan ziyaretçilerin ilgisini çeken görsel kalitesi yüksek alandır.

Uluabat Gölü çevresinde kültürel peyzajın en önemli bileşenleri köy yerleşimleridir. Erduran ve ark. (2012)' nın belirttiğine göre; yerel yaşamın ve bu yaşamın bileşenlerinin de gelecek nesillere aktarımının sağlanması gerekmektedir. Çünkü bu alanlar da ekoturizmin çok önemli destinasyonlarıdır.

Uluabat Gölü kıyısındaki köylerden Eskikaraağaç Köyü, eski dönemlerde köyün bir tarafında Türkler'in bir tarafında Rumlar'ın birlikte yaşamış oldukları ve günümüzde de leylekleri ile ünlü olan köydür. Bu köyde halk, leylekler konusunda oldukça duyarlı olup, leylekleri koruma altına almış ve leylekler için yuvalar yapmışlardır. Eskikaraağaç köyü, 2011 yılında Avrupa Tabiat Mirası Vakfı tarafından Avrupa Leylek Köyü seçilmiştir. Böylece bu alan, Avrupa'nın leylek köyleri ağının Türkiye'deki ilk ve tek temsilcisi olmuştur. Eskikaraağaç köyünde 15 yıldır iki gün süren ve çeşitli etkinliklerle gerçekleştirilen leylek festivali çok sayıda ziyaretçi çekmektedir. Köyde, yaban hayatı gözlemlemek için bir gözlem kulesi, yaban yaşamı gözlem evi, yaban hayatı müzesi, göl kıyısında bisiklet ve yürüyüş yolu bulunmaktadır.

Uluabat Gölü kıyısında bulunan diğer bir köy de Gölyazı köyüdür. Gölyazı köyü mevsimsel olarak değişen ada ya da yarımada görünümü dinamik peyzajı ile dünyaca ünlü bir turistik köydür. $\mathrm{Bu}$ köyün tarihçesi 2500 y1l öncesine ve Roma dönemine dayanmaktadır. Köyde, antik çağdan kalma taşların kullanıldığı cumbalı Rum evleri, antik surlar, Helenistik kapı ve kule kalıntıları, antik su kemeri, mezar yapıları, kilise, yel değirmeni, tarihi camii, hamam bulunmaktadır. Göl içerisindeki yedi adadan birisi olan Kız adasında antik Apollon tapınağı kalıntıları, antik tiyatro kalıntıları ve Manastır Adası'ndaki Hagios Konstantinos Manastırı kalıntıları ile bu alan birinci derece Arkeolojik sit statüsünde korunmaktadır. Bütün bunlara ek olarak Gölyazı köyünde bulunan ağlayan çınar (anıt çınat), bu alana özgü mitolojik hikayeler, kadın balıkçı geleneği, yöreye özgü yeme içme kültürleri, misafirsever köy halkı ile çekici bir turistik destinasyondur (Çelik ve ark., 2016).

Uluabat Gölünün kaynak değerlerinin günümüzde kullanım şekilleri; tarım ve hayvancılık, saz kesimi, balıkçılık, endüstriyel kullanım, evsel kullanım, turizm ve rekreasyondur. Göl çevresindeki köylerde yaşayan yerel halkın \% 15'inin geçim kaynağ tarımsal faaliyetlere dayanmakta, çeşitli sebze türlerinin yanısıra, zeytin yetiştiriciliği ve meyvecilik bölgenin tarımsal üretiminde 
önemli yer tutmaktadır. Tarımsal faaliyetler için gerekli olan sulama suyu gölden çekilmektedir. Sazlıklar, yetiştikleri sulak alanları dünyanın en üretken ekosistemleri hâline getirirler. Uluabat Gölü'nün sığ bir göl olması nedeni ile sazlık alanlar oldukça geniştir. Ördekler, kazlar, balıkçıllar, dalgıçlar, yağmurcunlar, karabataklar, pelikanlar, düdükçünler, saz bülbülleri, martılar, kaşıkçı kuşları, çeltikçiler, sumrular sulak alanları ve sazlıkları kendilerine yurt edinirler ve bu nedenle sazlıklar gölde ekosistemin önemli bir parçasını oluşturur. Bu alanda saz kesimi, çevre köylerdeki halkın geçim kaynağı arasında yer almaktadır. Ancak, çeşitli illerden gelenlerin de kontrolsüz saz kesimi yapması biyoçeşitliliğin korunmasında önemli sorunlardandır.

Balıkçılık yöre halkının \% 85'inin geçim kaynağı olup, göle sınırı olan 11 yerleşim alanı göldeki su ürünlerinden y1l boyu ve ekonomik olarak yararlanmaktadır. Gölde bulunan 21 balık türünden turna, sazan, yayın, tatlı su kefali, ringa balığı ve kızılkanat balıkları ticari amaçlı avlanmaktadır. Göldeki en önemli su ürünlerinden birisi de kerevittir. Gölde aşırı balıkçılık faaliyetleri gölün ekolojik durumunu olumsuz etkilemekte, balık popülasyonundaki değişim su bitkilerini ve kerevit popülasyonunu olumsuz etkilemektedir. Ayrıca bu durum suyun bulanıklığını da etkileyerek alanın görsel kalitesini bozmaktadır.

Gölün bulunduğu bölgedeki çeşitli sanayi tesisleri ile madencilik işletmelerinin kirletici vasfı yüksek olup, çoğunluğunda arıtma tesisi yok ya da yeterli değildir. $\mathrm{Bu}$ da göl ekosisteminin bozulmasina neden olmaktadır.

Uluabat Gölü kıyısında bulunan Gölyazı Köyü günümüzde çeşitli rekreasyonel faaliyetlerde bulunmak üzere turizm amaçlı kullanılmaktadır. Bu durum, yerel halkın ekonomik kalkınmasına katkı sağlamaktadır. Burada doğrudan suya dayalı olarak yapılan rekreatif faaliyetlerden birisi sandal gezintisidir. Diğer bir turizm türü avcılık olup, planlı bir şekilde yürütülmeyen bu turizm türünde de aşırı avlanmanın yanı sıra, yavrulama dönemindeki hayvanların rahatsız edilmesi söz konudur.

\section{Uluabat Gölü ve Çevresinde Yapılabilecek Sürdürülebilir Eko Turizm Türleri}

Sulak alanlar doğal ve kültürel peyzaj özellikleri ile ekoturizm bakımından vazgeçilmez alanlardır. Ancak bu alanlarda insan ve doğa arasındaki hassas ilişki bozulmamalıdır. Bu hassas mekanizma dış etkilerle bir defa bozulduğunda onu eski haline getirmek ya da düzeltmek oldukça güçtür. Bu alanların korunabilmesi için, sulak alanı besleyen kaynakların korunması ve alan yönetimi konusunda ilgili paydaşların sürece mutlaka dahil edilmesi gerekmektedir.

Sulak alanlar her türlü rekreasyon ve turizm faaliyetinde öncelikle ekolojik karakteri korunarak değerlendirilmelidir. Bu amaçla da kısıtlamalar, yasaklamalar, doğaya saygı ve yüksek çevre bilinci ile her türlü alt ve üst yapı tesisinde ekolojik tasarım gerektirmektedir. Rekreasyonel ve turistik faaliyetler, o yerde var olan rekreasyonel ve turistik tesislerin kabul edilebilir kapasitelerini aşmayacak bir düzeyde olmalı, sulak alanların rekreasyonel ve turistik kullanımlarında taşıma kapasitesi asla aşılmamalı ve alanın ekolojik dengesi bozulmamalıdır. Aynı şekilde alanın doğal estetiği de taviz verilmeksizin korunmalıdır.

Bu kapsamda Uluabat Gölü'nün doğal ve kültürel peyzaj özelliklerine uygun ve bu hassas eko sistemin bozulmadan simbiyotik bir ilişki içerisinde yapılabileceği eko-turizm çeşitleri belirlenmeye çalışılmış, suda yapılabilecek pek çok doğa sporları ve eko-turizm türü bu sebeple çalışmaya dahil edilmemiştir. Alanda sürdürülebilir turizm anlayışıyla ve koruma-kullanma dengesinde gerçekleştirilebilmesi uygun olan rekreasyon ve turizm türleri şunlardır:

Ornitoturizm: Kuşları doğal ortamlarında izlemeye dayanan kuş gözlemciliği diğer adıyla ornitoloji, bireysel yada toplu olarak gerçekleştirilen rekreasyonel aktivitelere denilmektedir (Sevindi, 2013). Uluabat Gölü geniş bir sulak alan olması ve kuş göç yolları üzerinde olması nedeni ile Türkiye'deki kuş gözlemciliği için en uygun alanlardan birisidir. Uluabat gölü geniş ve açık su yüzeyi ile kışlayan kuşlar için güvenli bir ortam oluşturmakta, zengin besin varlığı ile de kuşların beslenmesine imkan sağlamaktadır. Gölde kuş gözlemciliği tüm yıl ve gün içerisinde her saatte yapılabilmektedir. Ancak Uluabat gölü ve çevresinde kuş gözlemciliğine olanak sağlayan düzenlemeler bulunmamaktadır.

Botanik Turizmi: Biyolojik çeşitlilik rekreasyon ve turizm için de değerlendirilmektedir. Botanik turizmi, farklı bitkileri görme, bilme ve bu bitkilerin özelliklerini keşfetme isteğiyle gerçekleştirilen bir turizm türüdür (Albayrak, 2013). Bu turizm türü, alanında uzman rehber eşliğinde biyolojik çeşitliliğin tanıtılması şeklinde gerçekleşmektedir. Uluabat Gölü zengin ve çeşitlilik gösteren 
ekosistemleri, endemik bitki çeşitliliği ve floristik zenginliği, özellikle de su bitkileri bakımından Türkiye'deki en zengin göl olması nedeni ile botanik turizmine çok uygundur. Bu turizm türü için botanik konusunda uzman rehberlerin yetiştirilmesi ve bu turizm türünün tur organizasyonlarına dahil edilmesi gerekmektedir.

Yaban Hayatı (Fauna) Gözlemciliği: Doğal yaşam alanlarındaki faunanın gözlenmesidir. Doğal peyzaj özelliği gösteren, ormanlar, longozlar, kayalıklar, sulak alanlar, dağlar vb. alanlar farkl1 hayvan türlerinin yaşamasına olanak sağladığından yaban yaşamı gözlemciliği için uygun alanlardır. Yaban yaşamı gözlemciliği turizmi ise araştırmacıların yanında doğa tutkunlarının ilgi gösterdikleri turistik bir faaliyettir (Dartnell ve ark., 2015). Burada, insanların hayvanlara olan ilgileri bir endüstriye dönüşmüştür. Uluabat Gölü çevresinde yaşayan memeli türler (Su samuru, çakal, tilki, porsuk, tavşan) bu turizm türü için uygundur. Ancak bu faaliyette bulunacak olan kişilerin bir takım kurallara uyması gerekmektedir. Bunlar; yoğun ziyaretçiler hayvanların günlük faaliyetlerini olumsuz etkilememeli, insanların ilgisi hayvanların yetenek ve güdülerini kaybettirecek nitelikte olmamalıdır. Bu hayvanlar aynı zamanda küresel ölçekte nesli tehlike altında olan türler olduğundan ziyaretçilerin bilinçli olması gerekmektedir.

Foto Safari: Amatör ya da profesyonel olarak fotoğraf sanatı ile ilgilenenlerin doğa fotoğraf çekebilmeleri ve kendilerini geliştirebilmeleri için düzenlenen turlara Foto Safari denilmektedir (Polat Üzümcü ve Çelik Çanga, 2019). Bu turlar; bozulmamış doğal ve kültürel peyzajları tanımak, korumak, onlara duyulan ilgi ve sevgiyi artırmak, keşfetmek ve ölümsüzleştirmek amacı ile yapılmaktadır. Uluabat Gölü, flora ve faunası, manzara kalitesi ve yerel yaşamı ile bu turizm türü için çok uygundur. Turizmin bu türünü daha organize bir şekilde geliştirmek üzere turların düzenlenmesi ve aynı zamanda da kadraja girmesi muhtemel düzensizliklerin giderilmesi gerekmektedir.

Tarım Turizmi (Agroturizm): Tarımsal üretimin yapıldığı yörelerde gerçekleştirilen bir turizm türüdür. Tarım turizmi kırsal turizmden ve eko turizmden farklı olarak, sadece tarım alanlarını kapsar ve tüketicinin seyahat nedenini tarımsal ürünler oluşturur (Küçükaltan, 2002). Tarım turizmi ailelere yaşam tarzlarını sürdürme imkanı sunarken, tarımsal arazi, orman, nehir vb. doğal kaynakları koruma imkanını da vermekte (Veeck ve ark., 2016), yaban hayatın geliştirilmesine ve su kaynaklarının korunmasına katkı sağlayarak çevre üzerinde olumlu etki yaratmaktadır (Barbieri, 2013). Bu turizm türünde tarımsal üretim ve ürünler, doğrudan üreticiler tarafından ziyaretçilere sunulmaktadır. Çiftçi marketleri, yol kenarları tezgahları, çiftlikte konaklama ve yerel yiyecek-içecekleri tadım, eğlence ve kırsal alanı tanıma faaliyetleri vb. tarımsal turizmin en çok bilinen bileşenleridir. Uluabat gölü, tarımsal turizm açısından mevcut durumu ile yol kenarı tezgahlarında ziyaretçilere ürün sunan niteliktedir. Bu konuda, yeni ve ilgi çekici pazarlama stratejilerinin geliştirilmesi ve turizme de kazandırılması gerekmektedir. Ayrıca tarımsal faaliyetlerde birebir bulunmayı sağlayacak nitelikte konaklama alanlarının yapılması gerekmektedir.

Doğa Yürüyüșü: Doğal mekanlarda bireysel ya da grup olarak yapılan bir doğa sporu türüdür. Doğa yürüyüşleri insana özgürlük hissi yanında farklı bir yaşam biçimi yaşama konusunda da başarılıdır (Ardahan, 2012). Weaver (2001) doğa yürüyüşünün; yürüyüş yapmak, geleneksel bir köy ziyareti ve yerel halkla paylaşımda bulunmak, doğa ile baş başa kalmak, manzara seyretmek ve doğal yaşamı gözlemlemek, adrenalin dolu deneyimler yaşamak gibi bir takım aktiviteleri içerdiğini ifade etmektedir (Yılmaz, 2008). Uluabat gölü; iklim, topografik yapısının uygunluğu, zengin flora ve faunası ve görsel manzara kalitesi ile doğayı gözlemlemeye, çevresindeki köylerdeki kırsal yaşam ile doğa yürüyüşleri için önemli bir potansiyele sahiptir. Ancak henüz göl ve çevresinde belirlenmiş ve işaretlenmiş bir doğa yürüyüşü parkuru bulunmamaktadır.

Amatör Balıkçılık Turizmi/Sportif Olta Balıkçılı̆̆ı: Doğal alanlarda veya özel olarak oluşturulmuş avlaklarda turistlerin balık avlama amacıyla gerçekleştirdikleri turizm türü olarak tanımlanmaktadır. Ayrıca sportif olta balıkçılığı turistlerin sadece balık avlama amacıyla geldiği, yerel halk ile fazla temasın olmadığı ancak yerel balıkçılarında katıldığı küçük ölçekli balık yakalama turnuvalarının düzenlendiği bir turizm türü olarak da tanımlanmaktadır (Borch, 2004; Lovelock, 2008: aktaran: Bezirgan, 2019). Son yıllarda avlanma faaliyetlerinin çoğunluğunda yaygınlaşan yakala-bırak yaklaşımıyla beraber sportif olta balıkçılığının eko-turizmin bir türü olarak düşünülebileceği iddia edilmektedir. Araştırma alanı bir göl olup olta balıkçılığı için uygundur. Korunan bir alan olması nedeni ile burada olta balıkçılığının avlanma noktaları ve mevsimi belirlenerek bu alanlarda ve kontrollü olarak yapılması planlanmalıdır. 
Bisiklet Turizmi: Rekreasyon, tatil, dinlenme, spor vb. amaçlarla yapılan günübirlik gezilerden, uzun mesafeli turlara kadar kişinin aktif bisiklet kullanıcısı olduğu seyahatleri kapsamaktadır. Bisiklet turizmi genellikle aktif bisiklet kullananların bisikletle yapılan seyahatleri içermekte ancak bisiklet etkinliklerine izleyici olarak yapılan ziyaretler de bu tanıma dahil edilmekte, özellikle bisiklet etkinliklerini (festival/ tur/ yarışma) izlemek üzere yapılan seyahatler de pasif bisiklet turizmi olarak kabul edilmektedir (Çelik Uğuz ve Özbek, 2018). Bisiklet bir ulaşım aracı olarak diğer motorlu araçlarla karşılaştırıldığında çevre üzerinde olumsuz etkilerinin olmaması nedeni ile korunan bu alanda geliştirilmesi gereken bir rekreasyonel faaliyettir. Bu amaçla, burada bisiklet parkurlarının yapılarak rotaların belirlenmesi ile bisiklet turlarına açılması gerekmektedir.

Sandalla Gezinti: Uluabat gölünde yerel halk tarafından sunulan ve bir kısım yerel halk için geçim kaynăg 1 olan sandal turu yapılmaktadır. Bu alanda sandal gezileri, nilüferleri ve diğer su bitkilerini daha yakından gözlemlemeye, Gölyazı köyünü panoromik olarak görmeye, görüntülemeye de olanak sağladığı için ziyaretçilerin çok ilgisini çekmektedir. Bu faaliyetin kuşların beslenme ve üreme durumlarını olumsuz etkilemeyecek biçimde planlı ve sınırlı sayıda sandal olacak şekilde yapılması gerekmektedir.

Manzara Seyretme: Bu alan manzara seyretmek, gün batımını izlemek, doğa ile iç içe olmak, temiz havada dinlenmek, çiçeklerden ve kokularından faydalanmak, bir ağacı kucaklamak gibi pasif rekreatif faaliyetler için de uygun bir alandır. Bu amaçla ekolojik ilkelerle düzenlenmiş alanlar gerekmektedir.

Festival Turizmi: Festivaller, kültür, sanat, gelenek-görenek, dinsel vb. nedenler ile belirli bir bölgede ve belirli bir zamanda insanların katılımı ile gerçekleştirilen kutlamalardır (Albayrak, 2013). Festival turizmi ise, festivalleri ekonomik kalkınma yada destinasyonun ve çekici yerlerin pazarlanmasında bir araç olarak görmektedir (Getz, 2010). Uluabat gölü yakın çevresindeki köylerden Eskikaraağaç Köyünde yapılan "leylek festivali" de her yaş grubunun ilgisini çeken etkinlikleri ile her yıl haziran ayında iki gün süren etkinliklerle, 15 yıldır gerçekleştirilmektedir. Festival esnasında yapılan etkinlikler; fener alayı, konserler, yöresel ürün satışları, tekne turları, gezici kütüphane, çocuklar için oyunlar ve yarışlar, leylek gözlemleme, fotoğraf çekme gibi aktif ve pasif etkinliklerden oluşmaktadır. Bu festivale ek olarak kadın balıkçı geleneğini tanıtma ve sürdürme doğrultusunda festivaller, gastronomi festivali gibi bu alanı özgün yönleri ile tanıtacak festivaller düzenlenmelidir. Ancak festival esnasında özellikle yüksek sesli müzik yayınlarının, konserlerin olması kuşlar, yaban yaşamı ve leylekler için rahatsız edici olmaktadır. Bu nedenle festival etkinliklerinin doğaya ve doğal yaşama zarar vermeyecek etkinliklerden oluşması gerekmektedir.

Kamp-Karavan Turizmi: Karavanları ya da çadırları ile turizme katılan kişilere yönelik, park ve konaklama olanağı sunan tesislerde gerçekleştirilen turizm türü olup, bu tesisler için kamping sözcüğü kullanılmaktadır (Şenol, 2011: aktaran: Akpur ve Zengin, 2019). Türkiye'de Turizm Tesislerinin Belgelendirilmesine ve Niteliklerine İlişkin Yönetmelik 23. maddesinde; karayolları güzergahları ve yakın çevrelerinde, deniz, göl, dağ gibi doğal güzelliği olan yerlerde kurulan ve genellikle müşterilerin kendi imkanlarıyla geceleme, yeme-içme, dinlenme, eğlence ve spor ihtiyaçlarını karşıladıkları en az on ünitelik tesisler (Anonim, 2020b) kamping olarak tanımlanmıştır. Kampingler, doğa ile baş başa daha uzun süre vakit geçirmek isteyenler için çeşitli olanaklar sunmaktadır. Uluabat Gölü çevresi, hem konaklamalı gelmek isteyen ziyaretçiler için çadır ya da karavan kamp alanlarına hem de topografik yapı yönünden eko turizme uygun niteliktedir. Bu amaçla, alt yapısı çevresel bir duyarlıkla hazırlanmış alanlara gereksinim bulunmaktadır.

Köy Turları: Kentlerde yaşayan insanlar için köy hayatını deneyimlemek, stresten uzak, sakin, temiz havası, doğal gıdaları ve suyu ile son derece çekici turistik destinasyonlardır. Uluabat gölü çevresinde yer alan köyler, gerek geleneksel köy yaşamının sürdürülmesi ve yöresel ürünlerin bulunması, gerekse gölün manzarası ve eşsiz doğal güzelliğini yaşama olanağı sağlaması bakımından köy turları için caziptir. Özellikle Gölyazı köyü gibi kültürel ve doğal peyzaj bakımından zengin ve tanınmış bir köyün bu göl etrafında olması da avantajdır. Bu turizm türünün uygulanmasında da yerel halkın günlük etkinliklerini aksatmayacak, tehlikeye düşürmeyecek, köy taşıma kapasitesi dikkate alınarak planlanması gerekmektedir. 


\section{Sonuç ve Öneriler}

Günümüzde insanlar psikolojik ve fiziksel sağlıkları için doğa ile iç içe olabilecekleri alanlara yönelmektedir. Doğal çevre koşullarında gerçekleşen ve doğal alanlara, yerel kültürel özelliklere, geleneksel özgünlügü korumaya duyarlı turizm türü de eko-turizmdir. Eko-Turizm, doğal kaynaklara dayalı olan alternatif turizmin önemli bir parçasını oluşturmaktadır. Sulak alanların zengin biyolojik çeşitliliğe sahip olması sebebiyle doğal zenginlik müzeleri olarak kabul edilmesi onları ekoturizm bakımından da önemli bir çekim unsuru yapmaktadır. Bu bağlamda eko-turizm kapsamında sulak alanların değerlendirilmesi ve alana özgü turizm çeşitlerinin belirlenmesi; alana özgü kaynak değerlerinin, ekolojik süreçlerin, biyolojik çeşitliliğin, yerel kültürel özelliklerin değerini anlayarak korumayı ve sürdürülebilirliğini sağlar nitelikte yönetmeyi gerektirmektedir. Tüm sulak alanlar korunmalı ve akılcı kullanılmalıdır. Bu alanlara yönelik turizm planlamaları gerçekçi ve uygulanabilir nitelikte olmalıdır. $\mathrm{Bu}$ alanlarda koruma kültürüne dayanmayan turizm faaliyetleri, sulak alanların zarar görmesine ya da tamamen kaybına sebep olabilecektir.

Uluabat gölü ve çevresi, küresel ve bölgesel ölçekte önemli olan bir rekreasyon alanı ve turizm destinasyonudur. Göl ve çevresindeki biyoçesitliliği koruma amaçl1 kısıtlamalar, düzenlemeler ve tesisler yok ya da çok yetersizdir. Uluabat Gölü Ramsar statüsüne sahip olup, göldeki biyoçeşitliliği sürdürebilecek kanuni bir koruma ihtiyacını doğurmaktadır. Bu noktada izlenecek en iyi yol korunan alanda turizm ilişkisini simbiyotik bir yaklaşımla ele almaktır. Böylece sulak alanlarda hem ekosistem hizmetleri hem de turizm faaliyetleri tehlikeye atılmadan sürdürülebilecektir. $\mathrm{Bu}$ çalışmada, bu düşünceden hareketle Uluabat Gölü doğal ve kültürel çevre özelliklerinin turizm ile simbiyotik ilişkisi kurularak sürdürülebilir ekoturizm türleri ve rekreatif-turistik faaliyetler için de kriterler belirlenmiştir. Bu alan için uygun bulunan ekoturizm türleri; Ornitoturizm, Botanik Turizmi, Yaban Hayatı Gözlemciliği, Foto Safari, Tarım Turizmi (Agroturizm), Doğa Yürüyüşü, Sportif Olta Balıkçılığı, Bisiklet Turizmi, Festival Turizmi, Sandalla Gezinti, Manzara Seyretme, Kamp-Karavan Turizmi, Köy Turları olarak sıralanabilir. Bu kapsamda alanda sürdürülebilir ekoturizm yapılabilmesi için öneriler getirilmiştir. Buna göre;

Göldeki adalar ve göl çevresi turistik çekiciliği en fazla olan alanlardır. Bu alanların imara açılmaması, göl çevresinde gölü kirletecek tesislerin yapılmasına izin verilmemesi gereklidir.

$\mathrm{Bu}$ alan hassas bir peyzajdır. Bu nedenle alana yönelik her türlü plan kararları ve tasarım detayları da hassasiyetle geliştirilmelidir. Sulak alanların devamlılığı için suya dayalı olmayan turistik faaliyetlerin bile su kaynağı ile birlikte değerlendirilmesi gerekmektedir.

Hoş görünümler yaratan kamış ve saz bitkileri, yetiştikleri yörede yaşayan su kuşları için besin kaynağı ve barınak oluşturduğundan, hem kuşları korumak hem de manzara kalitesi ve buna bağlı olarak sürdürülebilir turizm açısından sazlıkların korunması gerekmektedir.

Burada, Eko turizme yönelik alt yapı eksiklikleri giderilerek eko turiste hizmet etmeye yönelik tesisler yapılmalıdır. Eko-turizm faaliyetlerinde bulunmak isteyen ziyaretçilere yönelik doğal yapıya uygun kamp ve konaklama tesisleri yapılmalıdır. Sportif Olta Balıkçılığ için yine doğal yapıya uygun iskeleler kurulmalı, alt yapı hazır hale getirilmeli, turizm ve rekreasyon faaliyetleri daha planlı ve çekici hale getirilmelidir. Göl çevresindeki her türlü etkinlik alanında olabildiğince çöp çıkaracak tüketimlerden sakınılmalı ve standartlara uygun olarak çöp toplama alanları, hijyenik tuvaletler tesis edilmelidir.

Ziyaretçilerin bulundukları alandaki canlı türleri hakkında bilgi edinmesi, hatta eğitim çalışmalarına katılması insan-doğa bağını daha da güçlendirecektir. Bu alanda turizm ve rekreasyon faaliyetleri kapsamında çocuk ve gençlere yönelik eğitim merkezleri kurulmalıdır.

Böylece, eko-turizm etkinliğinde bulunan kişilerin doğal ve kültürel değerlerin korunmasına yönelik davranış ve tutumları öğrenmelerine olanak sağlayan alanlar oluşturulmalıdır.

Göl çevresinde atıl olan alanlar belirlenerek, kente çeşitli ekolojik servisler sunan bir park ve rekreasyon alanına dönüştürülmelidir. Bu alan turizm ve rekreasyona yönelik hizmetin yanı sıra çevre eğitimi veren alanlar olarak da değerlendirilebilir.

Burada yeni düzenleme alanlarında yapılacak her türlü bitkilendirmede egzotik bitkiler yerine mutlaka yerel türler kullanılmalıdır. Böylece bu alan kuş türlerini ve göçmen su kuşlarını sulak alana çekerek eko-turizmin de gelişmesini sağlayacaktır. Yerel bitki kullanımı bu alanda nesli tükenmek üzere olan türler için habitat oluşturarak yine eko-turizme katkı sağlayacaktır. 
Tasarımda ve uygulamalarda her türlü yapı elemanı ve donatı elemanları doğal estetiğin devamlılığı ve tamamlayıcısı rollerinden dolayı doğal malzemeden (taş, doğal taş, ahşap, pişmiş toprak vb.) olmalıdır. Kesinlikle yapay malzemeler kullanılmamalıdır (plastik, beton, metal, yapay kauçuk, lastik vb.).

$\mathrm{Bu}$ alanda koruma kültürünün esas alındığı eko-turizmin geliştirilmesinde ziyaretçiler kadar yerel halkın da tutum ve bilinci çok önemlidir. Bu nedenle, yerel halkın da bu sürece dahil edilmesi ve aidiyet duygusu oluşturulması sağlanmalıdır.

Göl ve çevresinde hem turizmin hem de ekolojik alanların sürdürülebilirliği, alanın taşıma kapasitesine uygun kullanımı ile sağlanabilir. Bunun için de alan, doğal kaynak değerlerinin varlığını tehlike altına almayacak, tehdit etmeyecek miktarda ziyaretçi ağırlamalıdır. Bu durum ise bu alanda kaynak değerlerine uygun bir turizm planlamasını gerektirmektedir.

Burada eko turizmin gelişimini sağlayan kaynaklar, bu alana özgü olan ve korunan doğal kaynaklardır. Korunan kaynakların turizm amaçlı kullanımı da kanunlara uygun olmalıdır. Bazı doğa alanları araştırmacılar, uzmanlar, bu konuya ilgili/eğitimli ekoturistlere hitap etmektedir. Bu alanlar sayıca az olduğu için, bu alanlara farkındalığı yüksek özel ilgi turistleri dışında turist kabul edilmemeli ve sinırlı sayıda olmalıdır.

Uluabat Gölü’nün başlıca sorunları; endüstriyel kirlilik, su seviyesine yapılan müdahaleler, aşırı balıkçılık, yabancı tür balık salımı, kuş avcılığı, plansız ve kapasite üstü yapılan turizm faaliyetleri olarak sıralanmıştır (Anonim, 2010). Bu sebeple her ne kadar sürdürülebilir eko-turizm türü olsa da balıkçılık, kuş gözlemciliği gibi turizm türlerinin kritik noktalarda yapılmasına izin verilmemesi gereklidir. Sulak alan ekosistemlerinde eko turizmin sürdürülebilirliği, doğal su rejiminin ve buna bağlı gelişen biyoçeşitliliğin sürekliliğine bağlıdır. Bu alan için üretilecek olan eko turizm projeleri alanın doğal özelliklerinin sürekliliğini sürdürecek nitelikte olmalıdır.

\section{Kaynaklar}

Akpur, A., Zengin B., 2019. İznik Gölü ile Cevresinin Kamp Ve Karavan Turizm Potansiyelinin Değerlendirilmesi, Turizm ve Araştırma Dergisi. 8(2): 4-20.

Albayrak, A., 2013. Alternatif Turizm, Detay Yayıncilık, Ankara, 2013.

Anonim, 2010. Havza koruma eylem planlarının hazırlanması projesi -Susurluk havzası nihai raporu. Mülga Çevre ve Orman Bakanlığ 1 , Gebze, Kocaeli.

Anonim, 2016. https://tr.wikipedia.org/wiki/T\%C3\%BCrkiye\%27deki_g\%C3\%B6ller_listesi. Erişim Tarihi 07 Kasim 2016.

Anonim, 2019. http://emlakansiklopedisi.com/wiki/ramsar-alani. Erișim Tarihi 15 Ekim 2019.

Anonim, 2020a. https://tr.wikipedia.org/wiki/Uluabat Gölü. Erișim Tarihi 20 Nisan 2020.

Anonim, 2020b.https://www.mevzuat.gov.tr/MevzuatMetin/3.5.20058948.pdf. Erişim Tarihi 29 Nisan 2020.

Ardahan, F., 2012. Doğa yürüyüşü yapanların yaşam doyum düzeyleri ile duygusal zeka ve yaşam doyumu arasındaki ilișkinin incelenmesi. Mediterranean Journal of Humanities. I//1, 11-19.

Barbieri, C., 2013. Assessing the sustainability of agritourism in the US: a comparison between agritourism and other farm entrepreneurial ventures, Journal of Sustainable Tourism. 21(2):252-270.

Bezirgan, M., 2019. Burhaniye'nin sportif olta balıkçıllğg potansiyeli ve turizm açısından kullanılabilirliği. Balıkesir Üniversitesi Sosyal Bilimler Enstitüsü Dergisi. 22(41): 447-464.

Çelik, A., Polat Üzümcü, T., Çetin, İ., 2016. Bursa İli Gölyazı Köyü'nün açık hava rekreasyon potansiyeli. International Journal of Social and Economic Sciences. 6 (2): 32-40.

Çelik Uğuz, S., Özbek, V., 2018. Destinasyon sadakatini etkileyen faktörler. Bisiklet Turizmi ve Burhaniye Bisiklet Festivali Örneği. 6 ( 2): 84-102.

Çınar, Ş., Küçükkara, R., Balık, İ., Çubuk, H., Ceylan, M., Erol, K.G., Yeğen, V., Bulut, C., 2013. Uluabat (Apolyont) Gölü’ndeki balık faunasının tespiti, tür kompozisyonu ve ticari avcıllı̆ı̆ı türlere göre dağılımı. Journal of Fisheriessciences.Com . 7 (4): 309-316.

Çubuk, H., 2000. Uluabat Gölünde balıkçığa ait yasal düzenlemeler ve balıkçılık uygulamalarına ilişkin sonuç raporu. Eğridir Su Ürünleri Araştırma Enstitüsü Müdürlüğü, Eğridir/Isparta. 22s.

Dalkıran, N., Karacaoğlu, D., Dere Ş., Şentürk, E., Torunoğlu, T., 2006. Factors affecting the current status of a eutrophic shallow Lake (Lake Uluabat, Turkey): Relationships between water physical and chemical variables. Chemistry and Ecology. 22 (4): 279-298.

Dalkıran, N., 2015. Uluabat Gölü Ramsar alanı ve biyolojik zenginliği. Karacabey Sempozyumu, 01-03 Ekim 2015 Karacabey-BURSA. Bildiri Kitabı. Sayfa 191-210. 
Dartnell, P., Tate, G., Storlazzi, C., 2015. Marine Wildlife Observation Report, U.S. Geological Survey Research Cruise 2015-613-FA Northern Monterey Bay, California February 18-19.

Erduran, F., Uzun, O., Çetinkaya, G., Dilek, F., Açıksöz, S., 2012. Determination of the cultural landscape values of Lake Suğla in Turkey. Internatıonal Journal of Food, Agrıculture \&Environment (JFAE). 10 (2): 949-955.

Ertem, B., Akkaya, H., 1997. Uluabat gölünde yabancı ot sorunları konusunda yapılan çalışmalarla ilgili gezi raporu. DSİ İşletme Ve Bakım Dairesi Başkanlığı, Ankara.

Getz, D., 2010. The Nature and Scope of festival Studies, International Journal of Event Management Research, $5 / 1,1-47$.

Gülbahar, O., 2009. 1990'lardan günümüze Türkiye'deki kitle turizminin gelişimi ve alternatif yönelimler. Süleyman Demirel Üniversitesi, İİ̈BF Dergisi. 14(1): 151-177.

Güney, B., 2014. Havza Yönetim Planları İçerisinde Sulak Alanların Yeri, Kuş Ve Habitat Direktifleriyle Olan İlişkisi. T.C. Orman ve Su İşleri Bakanlığı, -Uzmanlık Tezi, Ankara.

Khabbazi, P.A., Yazgan, M.E., 2012. Kirsal peyzaj ve ekoturizm. International Journal of Social and Economic Sciences. 2 (2): 5-9.

Koçan, N., 2011. Mudurnu (Bolu) ve yakın çevresi peyzaj özelliklerinin ekoturizm kapsamında irdelenmesi. Gümüşhane Üniversitesi, Fen Bilimleri Enstitüsü Dergisi. 1 (1): 67-78.

Küçükaltan, D., 2002. Tarım Turizmi ve Türkiye'de Tarım Turizmi İşletmeciliği, 2. Turizm Şurası Bildirisi, 1. Cilt, 12-14 Nisan, Ankara, S. 143-159.

Ostrovskaya, E., Douven, W., Schwartz, K., Pataki, B., Mukuyu, P., Kaggwa, R., 2012. Capacity For Sustainable Management Of Wetlands: Lessons From The Wet Win Project. Environmental Science \& Policy, In Press, Corrected Proof, 18 September.

Ödemiş, M., Çalık, İ., 2019. Sürdürülebilir Turizm: Gösterge ve Ölçme Yaklaşımı kitabı içerisinde, 1.Bölüm: Sürdürülebilir Turizm kavramı, Tarihsel Gelişimi ve Göstergeler Yoluyla İncelenmesi, Editörler: Oğuz Türkay ve İsmail Çalık, Detay Yayıncılık: Ankara.

Polat Üzümcü, T., Çelik Çanga, A., 2019. Foto Safari Turizmi. Turizm Ansiklopedisi Türkiye. Turizm ve Ağırlama Endüstrisinin Temel Kavramları. Detay Yayınları: 1047. ISBN: 978-605-254-085-5. Yayınc1 Sertifika No: 13188. Matbaa Sertifika No: 26649. S, 167. Ankara.

Seçmen, Ö., Leblebici, E., 1997. Türkiye Sulak Alan Bitkileri ve Bitki Örtüsü E.Ü. Fen Fakültesi Kitaplar Serisi No : 158 , Bornova, İzmir, $404 \mathrm{~S}$.

Sevindi, C., 2013. Ekoturizm ve Kuş gözlemciliği açısından Kuyucuk Gölü Kuş Cenneti (Arpaçay-Kars). Türk Coğrafya Dergisi. Sayı 61: 63-76.

Tockner, K., Push, M., Borchardt, D., Lorang, M.S., 2010. Multiple stressors in coupled river-floodplain ecosystems. Freshwater Biology. 55 (1): 135-151.

Veeck, G., Hallett I.V., L., Che, D., Veeck, A., 2016. The economic contributions of agricultural tourism in Michigan, Geographical Review. 106 (3): 421-440.

Welch, G., Welch, H., 1998. Breeding Bird Survey of Uluabat Lake. Dhkd 78p.

WWF., 2008. Türkiye'deki Ramsar Alanları Değerlendirme Raporu. Türkiye (Doğal Hayatı Koruma Vakfi).

Yılmaz, H., 2008. Turizm Çeşitlendirmesi Kapsamında Ekoturizmin Ürünü Olarak Tatil Çiftlikleri: Türkiye'deki Tatil Çiftliklerine Yönelik SWOT Analizi, Afyon Kocatepe Üniversitesi Sosyal Bilimler Enstitüsü İşletme Ana Bilim Dalı, Doktora Tezi, Afyon.

Zaimoğlu, Z., Bozkurt, S., 2010. Yapay Sulak Alanlarda Atıksu Arıtımı, Nobel Kitabevi, Adana. 